\title{
CITRA PONDOK PESANTREN RIYADHUTTAFSIR MENURUT PERSEPSI DAN MINAT SANTRI SALAF
}

\author{
Muhammad Khotim Iskandar \\ Program Studi Pendidikan Agama Islam \\ Program Pascasarjana IAI-N Laa Roiba Bogor \\ mkhiskandar@as-syari.net
}

\begin{abstract}
Image is something that is abstract because it relates to beliefs, ideas and impressions obtained from a particular object either directly felt, through the five senses or obtain information from a source. As explained by Roesady, an image is a set of beliefs, ideas, and a person's impression of a particular object. The image of the Riyadhuttafsir boarding school is inseparable from the perception of students, alumni and the community who perceive according to their observations that this boarding school has a positive image. This response (acceptance) directly from students, alumni, and the community in the pesantren environment is in accordance with the results of interviews and observations in the field by researchers who explain that their perception of the Riyadhuttafsir boarding school is an experience of objects namely the Riyadhuttafsir boarding school which only studies the interpretation of science, or relationships obtained by summarizing information and interpreting messages from students, alumni or the community about the existence of the Riyadhuttafsir boarding school in Pagentongan, Bogor. Based on preliminary observations by researchers, what was felt by the community about the teaching and study of Tafsir in the Riyadhuttafsir Islamic Boarding School also confirmed what had been conveyed by the alumni of the boarding school. That the Riyadhuttafsir Islamic Boarding School succeeded in proving its work as a traditional Islamic boarding school which specifically studied interpretation in the Bogor Pagentongan region. Furthermore, the uniqueness of the hut from the existence of the hut is what makes the writer interested to explore and explore further about the perceptions, interests and image of the Riyadhuttafsir boarding school among students and alumni, as well as figures and communities around the boarding school will be the specialty of teaching methodology in Islamic boarding schools. Riyadhuttafsir is timelessly eroded by the changing times. In accordance with the above research title, problem formulation and research objectives, this study uses a qualitative research design. In this study the approach used is a qualitative approach that is displayed as it is. According to Bogdan and Taylor, as quoted by Lexi Moleong, qualitative research is a research procedure that produces descriptive data in the form of written or oral words from people and the observed behavior.
\end{abstract}

Keywords: boarding school, image, interest, perception, student

\section{ABSTRAK}

Citra merupakan sesuatu yang bersifat abstrak karena berhubungan dengan keyakinan, ide dan kesan yang di peroleh dari suatu obyek tertentu baik dirasakan secara langsung, melalui panca indra maupun mendapatkan informasi dari suatu sumber. Seperti yang dijelaskan oleh Roesady, citra adalah seperangkat keyakinan, ide, dan kesan seseorang terhadap suatu object tertentu. Adapun citra pondok 


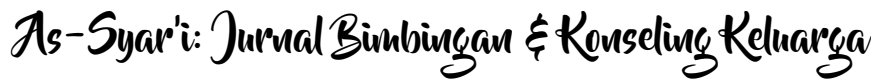

pesantren Riyadhuttafsir ini tidak terlepas dari persepsi santri, alumni dan lingkungan masyarakat yang mempersepsikan sesuai pengamatan mereka bahwa pondok pesantren ini citranya positif. Tanggapan ini (penerimaan) langsung dari santri, alumni, dan masyarakat di lingkungan pesantren sesuai dari hasil wawancara dan obsevasi di lapangan oleh peneliti yang menjelaskan bahwa persepsi mereka terhadap pondok pesantren Riyadhuttafsir adalah pengalaman tentang obyek yaitu pondok pesantren Riyadhuttafsir yang hanya mengkaji ilmu tafsir, atau hubungan-hubungan yang diperoleh dengan menyimpulkan informasi dan menafsirkan pesan baik itu dari santri, alumni atau masyarakat tentang keberadaan pondok pesantren Riyadhuttafsir di Pagentongan Bogor. Berdasarkan observasi awal oleh peneliti, apa yang dirasakan masyarakat akan pengajaran dan kajian keilmuan Tafsir di Pondok Pesantren Riyadhuttafsir juga membenarkan apa yang sudah disampaikan oleh alumni pondok pesantren ini. Bahwa Pondok Pesantren Riyadhuttafsir berhasil membuktikan kiprahnya sebagai pondok pesantren tradisional yang secara khusus mempelajari ilmu tafsir di wilayah Pagentongan Bogor. Lebih jauh, keunikannya pondok dari eksistensi pondok itulah yang membuat penulis tertarik untuk mendalami dan menelaah lebih jauh tentang persepsi, minat dan citra pondok pesantren Riyadhuttafsir di kalangan santri dan alumni, juga tokoh dan masyarakat sekitar pondok pesantren akan ke-khasan metodologi pengajaran di pondok pesantren Riyadhuttafsir yang tidak lekang tergerus perubahan zaman. Sesuai dengan judul penelitian di atas, rumusan masalah dan tujuan penelitian, maka penelitian ini menggunakan desain penelitian kualitatif. Dalam penelitian ini pendekatan yang digunakan adalah pendekatan kualitatif ditampilkan sesuai dengan apa adanya. Menurut Bogdan dan Taylor sebagaimana yang dikutip oleh Lexi Moleong menyebutkan bahwa penelitian kualitatif adalah prosedur penelitian yang menghasilkan data deskriptif berupa kata-kata tertulis atau lisan dari orang-orang dan prilaku yang diamati.

Kata kunci: citra, minat, pesantren, persepsi, santri

\section{A. PENDAHULUAN}

\section{Latar Belakang Masalah}

Pesantren merupakan lembaga pendidikan Islam di Indonesia yang perannya cukup besar dalam penyebaran ajaran agama Islam. Menurut catatan sejarah, Pesantren mempunyai kaitan yang erat dengan tempat pendidikan yang khas bagi kaum sufi. Hal ini ditandai oleh terbentuknya kelompok organisasi tarekat yang melaksanakan amalan-amalan zikir dan wirid tertentu. Disamping mengajarkan amalan-amalan tarekat, para pengikut itu juga diajarkan agama dalam berbagai cabang ilmu pengetahuan agama Islam yang dikenal dengan kegiatan pengajian. Dalam perkembangan selanjutnya lembaga pengajian ini tumbuh dan berkembang menjadi lembaga Pesantren.

Selain pendapat bahwa pondok pesantren merupakan lembaga pendidikan islam tertua di Nusantara, sejumlah sejarawan juga menyebut eksistensi pesantren lebih dulu hadir sebelum kedatangan bangsa Eropa di Nusantara pada Abad ke-16. Istilah pesantren merujuk pada tempat belajar bagi kaum intelektual Muslim yang dinamakan santri. Mereka mewarisi dan memelihara keberlanjutan tradisi keilmuan Islam sehingga sampai kepada dakwah Rasulullah SAW. Sanad atau rentetan transmisi keilmuan begitu dihargai di sana. Mereka pada umumnya mempelajari ragam keilmuan, mulai dari tata Bahasa Arab (Nahwu dan Sharaf), ilmu Tafsir dan membaca AlQur'an (Qiraat), Tauhid, Fiqh empat Mazhab (khususnya Imam Syafi'i), Akhlak, Mantiq, Sejarah (Tarikh), hingga Tasawuf. Selain itu, aksara Jawi, yakni huruf Arab dengan bahasa Melayu, kian memantapkan signifikansi pesantren sebagai pusat transfer ilmu yang menjaga corak khas Nusantara di tengah-tengah dunia Islam. 


\section{As-Syari: Jurnal Bimbingan E⿱ Konseling Keluarga}

Pondok Pesantren Riyadhuttafsir yang terletak di Kecamatan Ciomas, Pagentongan, Bogor, merupakan salah satu lembaga pendidikan Islam yang memiliki orientasi da'wah islamiyah untuk mencetak mundzirul qoum yang mutafaqqih fii ad-dien dalam hal kajian ilmu tafsir. Ciri khas Pondok Pesantren Riyadhuttafsir hingga saat ini masih menerapkan metode bandongan dengan ciri khas bidang keilmuan yang konsisten, yaitu Ilmu Tafsir Al-Qur'an ditengah perkembangan metode pendidikan yang mengikuti kemajuan teknologi, animo santri, dan masyarakat yang tinggi atas kajian yang beragam dan metode pengajaran modern saat ini.

Selain itu Pondok Pesantren Riyadhuttafsir juga mempunyai keunikannya berbeda dan jarang ditemukan di pesantren-pesantren yang lain yang secara umum di pesantren yang lain mempelajari bidang kajian ilmu yang diantaranya ilmu nahwu sharaf, ilmu fiqih, kajian kitab kuning, dan ilmu yang lainnya, namun di pesantren ini dikhususkan mempelajari ilmu tafsir saja yang menggunakan dari referensi kitab induknya yaitu tafsir Jalalain dan di tunjang dan disempurnakan dengan kitab tafsir yang lain, dengan biayanya pun terjangkau. Hal inilah yang menjadi citra positif dari masyarakat tentang keunikan pondok pesantren Riyadhuttafsir ini berbeda dengan yang lainnya, sehingga minat masyarakat terhadap pondok pesantren Riyadhuttafsir sangat antusias untuk mendalami dan mengkaji ilmu tafsir.

\section{Rumusan Masalah}

Adapun permasalahan penelitian yang berkaitan dengan citra pondok pesantren Riyadhuttafsir dimata publik dengan penjelasan yang terurai di atas, maka dapat dirumuskan beberapa pokok permasalahan yang menghasilkan beberapa pertanyaan, diantaranya yaitu:

1. Bagaimana persepsi santri, alumni, dan masyarakat pada Pondok Pesantren Riyadhuttafsir?

2. Bagaimana minat santri, alumni dan masyarakat pada pendidikan dan kajian khusus ilmu tafsir di Pondok Pesantren Riyadhuttafsir?

3. Bagaimana citra Pondok Pesantren Riyadhuttafsir dimata santri, alumni, dan masyarakat yang tinggal disekitar Pondok Pesantren Riyadhuttafsir?

\section{Tujuan Penelitian}

Berdasarkan pada batasan masalah di atas, dalam tujuan penelitian dalam studi ini adalah:

1. Untuk mendapatkan gambaran tentang persepsi santri, alumni, dan masyarakat pada Pondok Pesantren Riyadhuttafsir

2. Untuk mendapatkan gambaran tentang minat santri, alumni, dan masyarakat pada sistem, metode dan pembelajaran kajian khusus ilmu tafsir di Pondok Pesantren Riyadhuttafsir

3. Untuk mendapatkan gambaran citra Pondok Pesantren Riyadhuttafsir dari sudut pandang santri, alumni, dan masyarakat yang tinggal disekitar komplek lembaga pendidikan Pondok Pesantren Riyadhuttafsir ini.

\section{Hipotesis Penelitian}

Berdasarkan observasi awal oleh peneliti, apa yang dirasakan masyarakat akan pengajaran dan kajian keilmuan Tafsir di Pondok Pesantren Riyadhuttafsir juga membenarkan apa yang sudah disampaikan oleh alumni pondok pesantren ini. Bahwa Pondok Pesantren Riyadhuttafsir berhasil membuktikan kiprahnya sebagai pondok pesantren tradisional yang secara khusus mempelajari ilmu tafsir di wilayah Pagentongan Bogor. Lebih jauh, keunikannya pondok dari eksistensi pondok itulah yang membuat penulis tertarik untuk mendalami dan 


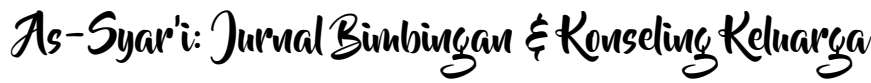

menelaah lebih jauh tentang persepsi, minat dan citra pondok pesantren Riyadhuttafsir di kalangan santri dan alumni, juga tokoh dan masyarakat sekitar pondok pesantren akan kekhasan metodologi pengajaran di pondok pesantren Riyadhuttafsir yang tidak lekang tergerus perubahan zaman.

\section{B. TINJAUAN LITERATUR}

\section{Kerangka Berpikir}

Sistematika penulisan dalam penelitian berfungsi memberikan kemudahan dalam memahami penelitian serta memberikan gambaran menyeluruh secara garis besar tentang isi penelitian. Adapun sistematika penulisan dalam penelitian ini dapat disusun sebagai berikut:

Pada bab satu menerangkan tentang Latar Belakang Masalah, Rumusan Masalah, Tujuan Penelitian, Manfaat Penelitian, Kerangka Pemikiran, dan Sistematika Penulisan.

Pada bab dua mengurai tentang teori-teori baik definisi dan pengertiannya. Uraian pada bab ini difokuskan kepada inti dari rumusan masalah tentang Citra Pondok Pesantren Riyadhuttafsir di Mata Publik.

Pada bab tiga menjelaskan gambaran umum tentang jenis penelitian, definisi konsep, teknik pengumpulan data, teknis analisis data, dan lokasi penelitian.

Pada bab empat akan dijelaskan mengenai gambaran obyek penelitian diantaranya Profil Pondok Pesantren Riyadhuttafsir, temuan lapangan yang berisi tentang diskusi, wawancara, observasi serta interpretasi, dan juga akan dijelaskan berupa penyajian dan analisis data, untuk menarik kesimpulan menjawab masalah yang telah dirumuskan. Fungsi bab empat ini adalah pemaparan data yang diperoleh dilapangan.

Pada bab lima berisikan tentang kesimpulan dan saran yang dikemukakan dari hasil analisis dan pemecahan masalah dalam penelitian ini. Dapat juga berisikan rekomendasi kepada lembaga pendidikan Islam.

\section{METODOLOGI PENELITIAN}

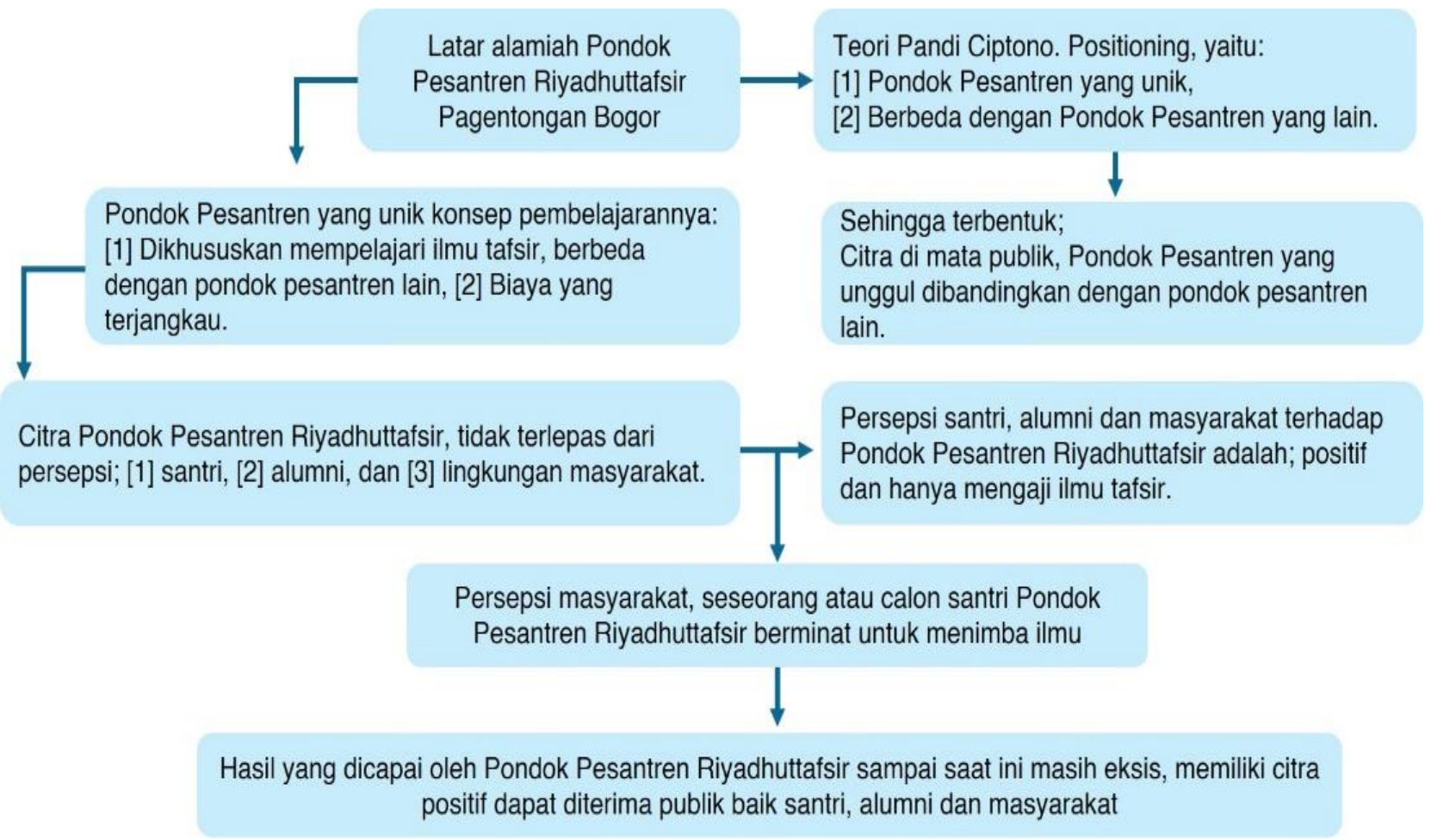




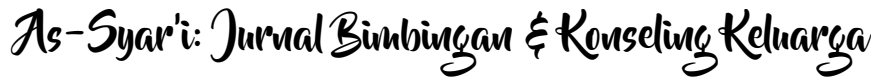

Pendekatan dan Jenis Penelitian

Penelitian merupakan suatu sarana untuk mengembangkan ilmu pengetahuan, baik dari segi teoritis maupun praktis. Penelitian merupakan suatu bagian pokok dari ilmu pengetahuan, yang bertujuan untuk lebih mengetahui dan lebih mendalami segala segi kehidupan.

Penelitian ini bertujuan mendapatkan gambaran mendalam tentang Citra pondok pesantren Riyadhuttafsir dimata publik. Untuk mendapatkan data deskriptif berupa kata-kata tertulis, perbuatan dan dokumentasi yang diamati secara menyeluruh dan apa adanya, penulis menggunakan pendekatan kualitatif ini berdasarkan beberapa pertimbangan. Pertama, menyesuaikan metode kualitatif lebih mudah apabila berhadapan dengan kenyataan jamak. Kedua, metode ini menyajikan secara langsung hakikat hubungan antara peneliti dan responden. Ketiga, metode ini lebih peka dan lebih dapat menyesuaikan diri dengan banyak penajaman pengaruh bersama terhadap pola-pola nilai yang dihadapi.

Sesuai dengan judul penelitian di atas, rumusan masalah dan tujuan penelitian, maka penelitian ini menggunakan desain penelitian kualitatif. Dalam penelitian ini pendekatan yang digunakan adalah pendekatan kualitatif ditampilkan sesuai dengan apa adanya. Menurut Bogdan dan Taylor sebagaimana yang dikutip oleh Lexi Moleong menyebutkan bahwa penelitian kualitatif adalah prosedur penelitian yang menghasilkan data deskriptif berupa kata-kata tertulis atau lisan dari orang-orang dan prilaku yang diamati.

Penelitian ini masuk dalam penelitian kualitatif, sebab pendekatan yang dilakukan adalah melaui pendekatan kualitatif deskriptif, artinya dalam penelitian kualitatif data yang dikumpulkan bukan berupa angka-angka melainkan data tersebut berasal dari wawancara, catatan lapangan, dokumen pribadi, dokumen resmi dan lainnya.

\section{Lokasi Penelitian}

Penentuan lokasi selain dibingkai dalam kerangka teoritik juga dilandasi oleh pertimbangan teknis operasional. Untuk itu lokasi penelitian dipertimbangkan berdasarkan kemungkinan dapat tidaknya dimasuki dan dikaji lebih mendalam. Mengenai lokasi penelitian yaitu:

Pondok Pesantren Riyadhuttafsir yang terletak di Kp. Babakan Pagentongan Ciomas Kabupaten Bogor Jawa Barat,

Lokasi sebaran alumni Pondok Pesantren Riyadhuttafsir yang terletak di wilayah Provinsi Banten, Provinsi Jawa Barat dan Provinsi DKI Jakarta,

Kampung Babakan Pagentongan Kecamatan Ciomas Kabupaten Bogor.

\section{Subjek dan Objek Penelitian}

Lokasi objek penelitian tersebar berdasarkan kebutuhan akan data dan informasi. Subjek penelitian ini adalah para santri dan alumni Pondok Pesantren Riyadhuttafsir yang berada di wilayah Bogor, Provinsi Banten, dan sekitar Cianjur dan Bandung. Juga tokoh-tokoh dan informan yang berdekatan dengan lembaga pendidikan di Kampung Babakan, Pagentongan.

\section{Sumber Data}

Yang dimaksud dengan sumber data dalam penelitian adalah subyek dari mana data diperoleh. Adapun sumber data yang diambil oleh penulis dalam penelitian ini adalah sumber data utama yang berupa kata-kata dan tindakan, serta sumber data tambahan yang berupa dokumen-dokumen. 


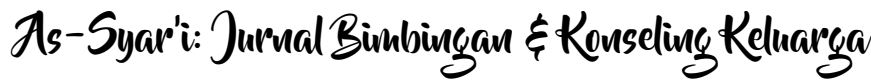

Data primer adalah data yang langsung diperoleh dari sumber pertama dilokasi penelitian. Dalam penelitian ini sumber data primernya yakni data yang diperoleh dan dikumpulkan langsung dari informannya, dimana informan disini dari seseorang yang berpotensi untuk memberikan informasi yang kita butuhkan sebagaimana Pimpinan Pondok Pesantren, Keluarga Pimpinan, Dewan Guru, Santri, Alumni dan Tokoh serta warga masyarakat sekitar.

Data sekunder adalah data yang bersumber dari dokumen-dokumen, foto-foto, dan bendabenda yang dapat digunakan sebagai pelengkap data primer. Dengan kata lain bahwa data sekunder ini data yang diperoleh dalam bentuk yang sudah jadi yakni yang sudah dipublikasikan. Adapun sumber data sekunder dari penelitian ini adalah data yang diolah lebih lanjut dan dipublikasikan oleh pihak lembaga yang diteliti. Dalam penelitian ini sumber data sekunder diambil dari buku buku penunjang, dokumen Pondok Pesantren, dan foto-foto.

\section{Teknik Pengumpulan Data}

Pengumpulan data adalah prosedur yang sistematik dan standar untuk memperoleh data yang diperlukan. Dalam usaha mengumpulkan data, peneliti berusaha mencari informasiinformasi yang berkaitan dengan fokus dalam penelitian ini, baik berupa pendapat, fakta-fakta maupun dokumentasi.

Adapun metode pengumpulan data yang digunakan oleh peneliti ada tiga metode, yaitu observasi partisipan, wawancara mendalam dan dokumentasi.

\section{Teknik Pengolahan Data}

Tahapan pengolahan data yaitu proses editing, dimana semua data diperiksa dan diedit pada bagian yang tidak diperlukan. Setelah semua selesai, data yang sudah diperiksa dan diedit akan dianalisa dan ditafsirkan dalam bentuk deskriptif.

\section{Pengecekan Keabsahan Data}

Untuk mendapatkan data yang lebih relevan dan urgen terhadap data yang terkumpul, maka peneliti menggunakan teknik triangulasi, yaitu teknik pemeriksaan keabsahan data yang memanfaatkan sesuatu yang lain di luar data itu untuk keperluan pengecekan atau sebagai perbandingan terhadap data itu. Dalam penelitian ini penulis menggunakan triangulasi yang berdasarkan dengan sumber yang artinya membandingkan dan mengecek balik derajar kepercayaan suatu informasi yang diperoleh melalui waktu dan alat yang berbeda dalam penelitian kualitatif.

\section{Prosedur Penelitian}

Dalam melakukan penelitian ini peneliti membaginya kedalam tiga tahapan yaitu: tahap pralapangan, tahap kegiatan lapangan, dan tahap analisis data.

\section{HASIL DAN PEMBAHASAN}

Objek Penelitian Alumni dan Santri Salaf di Pondok Pesantren Riyadhuttafsir

Penelitian ini berfokus pada persepsi, minat dan citra santri, alumni dan masyarakat sekitar terhadap Pondok Pesantren Riyaduttafsir dalam melakukan kegiatan pesantrennya. Selain itu juga terfokus pada cara-cara pondok pesantren dalam meningkatkan citranya di mata masyarakat sehingga pondok pesantren ini mendapat penilaian baik dari masyarakat. 


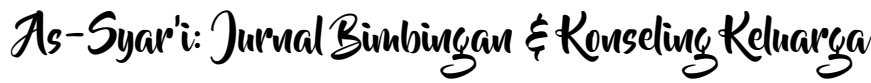

Profil Pondok Pesantren Riyadhuttafsir dirintis dan dipimpin oleh seorang tokoh kiai yang memiliki niatan murni untuk membangun kekuatan Islam melalui jalur kajian ilmu tafsir, yaitu K.H. Asep Saepuddin, MA. Kiprahnya dalam mengelola pendidikan pesantren dimulai sejak tahun 1980-an. Pada awal berdirinya Pesantren, kajian yang didalami mencakup bidang keilmuan yang umumnya dipelajari di Pondok Pesantren. Diantaranya, ilmu Nahwu, Shorof, Fiqh, Ushul Fiqh, Tafsir, Hadist, Bayan, Tasawuf, Hikmah, hingga Muhadhoroh dan Mudzakaroh untuk beberapa bidang keilmuan.

Visi dan Misi: "Menjalankan dakwah Islamiyah untuk membangun manusia seutuhnya supaya benar-benar menjadi orang yang sempurna atau insanun kamilun"

Letak Geografis

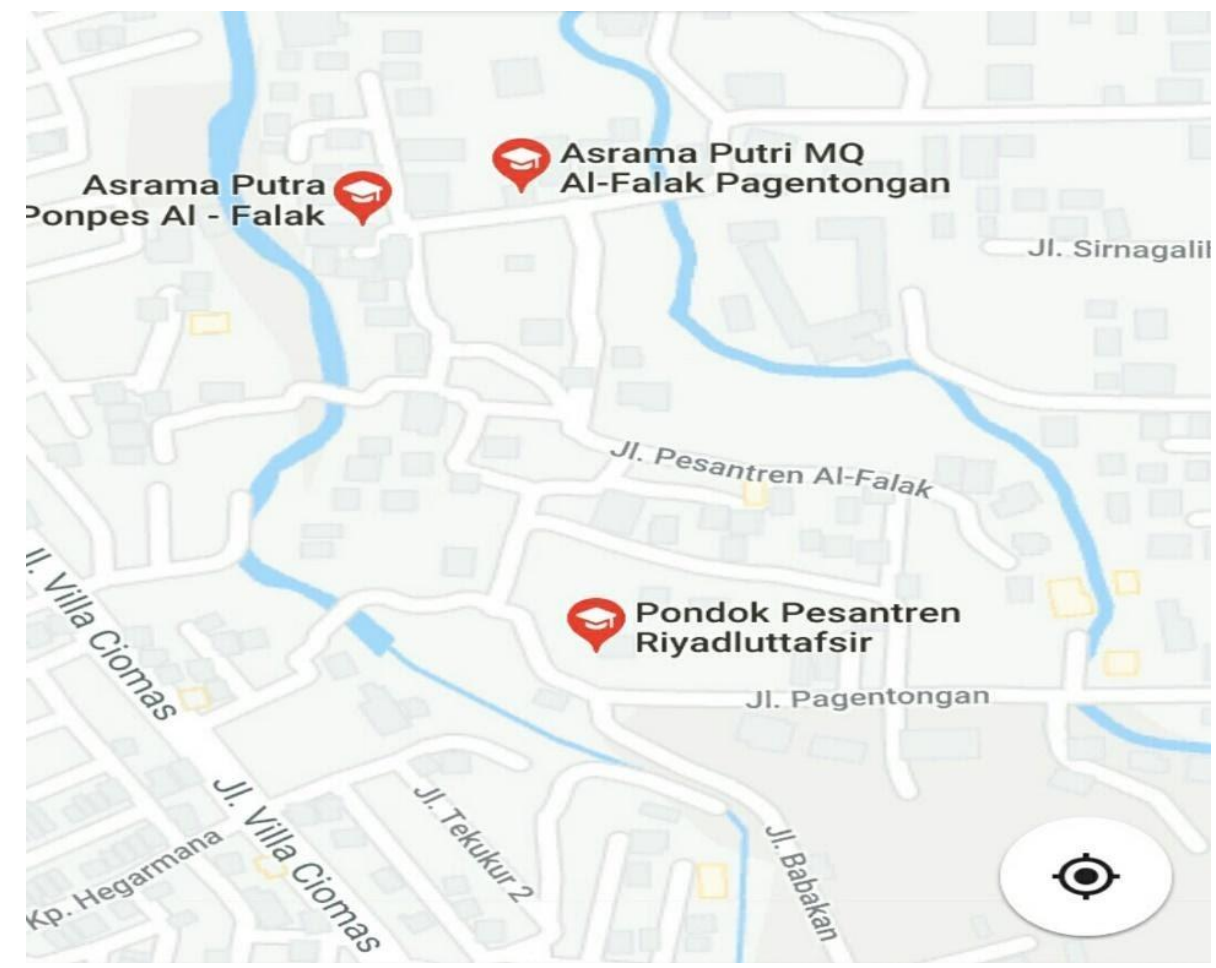

Temuan Lapangan

Dari hasil wawancara yang dilakukan penulis terhadap santri, alumni dan masyarakat yang tinggal disekitar pondok pesantren Riyadhuttafsir, didapatkan temuan bahwa pondok pesantren Riyadhuttafsir dirasakan, diterima dan dianggap sebagai pondok pesantren yang secara spesifik dan konsisten mengajarkan bidang keilmuan tafsir saja.

Persepsi Santri terhadap Pondok Pesantren Riyadhuttafsir. Persepsi santri dan masyarakat merupakan suatu proses kognitif dimana santri dan masyarakat menginterpretasikan serta memberikan penilaian dan pemaknaan yang berbeda-beda terhadap rangsangan atau stimulus, termasuk respon terhadap metode pengajaran dan suasan pembelajaran di Pondok Pesantren Riyadhuttafsir. Apabila santri dan masyarakat memiliki persepsi yang positif maka sikap dan perilaku terhadap kegiatan belajar mengajar, kondisi dan sistem pendidikan yang diterima akan baik, demikian juga sebaliknya. Adapun temuan lapangan yang sudah dilakukan peneliti yang merupakan hasil penelitian baik itu dari hasil observasi atau wawancara tentang persepsi santri terhadap pondok pesantren Riyyaduttafsir Pagentongan Bogor. 


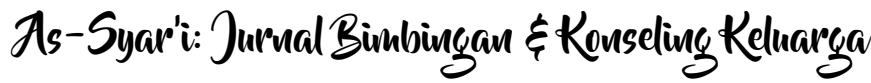

Persepsi Alumni Terhadap Kegiatan yang dilakukan di Pondok Pesantren Riyadhuttafsir. Persepsi alumni terhadap Pondok Pesantren Riyadhuttafsir sebagaimana hasil wawancara, pondok pesantren adalah lembaga pendidikan yang dipersepsikan mengajarkan bidang keilmuan atau kaidah ilmu tafsir yang dipadankan dengan pisau analisa dari bidang keilmuan lain seperti ilmu nahwu, ilmu hadist, ilmu mustholah hadist, dan ilmu mustholah tafsir. Pondok pesantren Riyadhuttafsir tidak hanya menjelaskan ilmu tafsir secara kajian lughot atau teks per teks dari kitab Tafsir Jalalain, namun juga menjelaskan dengan tiga aspek pendekatan yaitu, tafsir biddiroyah, tafsir birriwayah, dan tafsir bilisyaroh. Konsistensi pengajaran dan metode pendidikan ilmu tafsir dengan ciri khas tersebut, menjadikan pondok pesantren Riyadhuttafsir dipersepsikan sebagai pondok pesantren yang menaruh kaidah penjabaran baru dalam menyelami kandungan isi Al-Qur'an. Metode tersebut juga dipengaruhi dengan karakter dan sosok pengasuh yang dianggap fleksibel dan lugas dalam menjabarkan kaidah serta wawasan ilmu tafsir. Bahkan menurut penyampaian Pendiri sekaligus Pengasuh pondok pesantren Riyadhuttafsir, hal tersebut dilakukan sebagai jalan untuk memberikan pemahaman utuh kepada santri dan para kiai tentang bagaimana memahami teks dari berbagai sudut pandang, terutama menurut empat Madzhab yang dianut oleh Ahlussunnah wal Jama'ah.

\section{E. KESIMPULAN}

Pondok Pesantren Riyadhuttafsir merupakan salah satu pondok pesantren yang dikhususkan untuk mengkaji dan mempelajari ilmu tafsir saja. Keunikannya berbeda dengan pesantren-pesantren yang lain yang secara umum mempelajari bidang kajian ilmu yang diantaranya ilmu nahwu sharaf, ilmu fiqih, kajian kitab kuning, dan ilmu yang lainnya, namun di pesantren ini dikhususkan mempelajari ilmu tafsir saja yang menggunakan dari referensi kitab induknya yaitu tafsir Jalalain dan di tunjang dan disempurnakan dengan kitab tafsir yang lain, dengan biayanya pun terjangkau.

Adapun citra pondok pesantren Riyadhuttafsir dimata publik ini tidak terlepas dari persepsi santri, alumni dan lingkungan masyaraat yang mempersepsikan sesuai pengamatan mereka bahwa pondok pesantren ini citranya positif, sehingga pesantren ini diminati banyak orang terutama para kiai atau ustadz yang ingin mempertajam ilmu tentang tafsir. Pengasuh atau pak kiai selaku pemimpin pondok pesantren ini menggunakan citra perusahaan atau teori positioning produk yang dikemukakan Fandi Tjiptono yaitu strategi yang berusaha menciptakan perbedaan yang unik kepada sasaran produk, sehingga terbentuk citra pada pelanggan yang unggul dibandingkan dengan pesaing.

\section{DAFTAR PUSTAKA}

Abady, H M Yusrie, Corak Pemikiran Pendidikan Keagamaan K.H. Abdur Rahman Ambo Dalle, (Ciputat. Rabbani Press, 2012).

,Pedoman Penulisan Karya Ilmiah (Skripsi, Tesis, Disertasi), (Ciputat, Rabbani Press, 2011).

Konsepsi dan Praksis Politik Islam AQM, (Ciputat, Rabbani Press, 2012).

Abdulllah, Jalaludin, Filsafat Pendidikan, Jogjakarta: (Ar Ruzz Media, 2012).

Akdon, Strategic Manajement for Educational Management (manajemen Strategik untuk Manajemen Pendidikan), (Bandung: Alfabetta, 2007), Cet, 2.

Ahmadi, Abu. Cara Belajar yang Mandiri dan Sukses. (Solo: Aneka, 1993). 


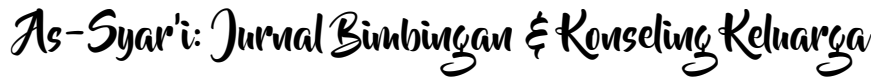

Ahmadi, Abu. Psikologi Umum. (Jakarta: Rieka Cipta. 2009).

Alwi, Hasan. Kamus Besar Bahasa Indonesia, (Jakarta: Balai Pustaka. 2007).

A.M. Sardiman. Interaksi dan Motivasi Belajar Mengajar. (Jakarta: PT. Raja Grafindo Persada, 1996).

Arikunto, Suharsim. Prosedur Penelitian Suatu Pendekatan Praktek, (Jakarta: Rineka Cipta, 2002),

Arikunto, Suharsimi. Prosedur Penelitian Suatu Pendekatan Praktik, 87. (Jakarta: Rineka Cipta, 2010).

Anggoro, M Linggar. Teori dan Profesi Kehumasan. (Jakarta: PT. Bumi Aksara. 2001).

Ardianto, Alvinaro. Handbook of Public Relations. Pengantar Komprehensif. (Bandung: Remaja Rosdakarya. 2011).

Ardianto, Elvinaro. Metodologi Penelitian untuk Public Relations Kuantitatif dan Kualitatif. (Bandung: Simbiosa Rekatama Media. 2011).

Benda, Harry J. Bulan Sabit dan Matahari Terbit: Islam Indonesia pada Masa Pendudukan Jepang. (Jakarta: Dunia Pustaka Jaya, 1980).

Bisri, Cik Hasan, Penuntun Penyusunan Rencana Penelitian dan Penulisan Skripsi, (Jakarta, Raja Grafindo Persada, 2001)

Bruinessen, Van, Kitab Kuning, Pesantren Dan Tradisi Islam Di Indonesia, (Bandung: Mizan, 1999).

Buchori, M. Psikologi Pendidikan. (Jakarta:PT. Rineka Cipta. 1991).

Crow and Crow. An Outline of Psicology (Terjemahan Z. Kazijan) (Surabaya: PT. Bina Ilmu, 1973).

Dhofier, Zamakhsari. Tradisi Pesantren "Studi Pandangan Hidup Kyai dan Visinya Mengenai Masa Depan Indonesia" (Jakarta: LP3ES, 2011).

Depdikbud. Psikologi Pendidikan. (Jakarta: Depdikbud, 1982/1983).

Dewan Redaksi Ensiklopedi Islam, Ensiklopedi Islam, Cet.1, jilid IV, (Jakarta Ichtiar Baru van Hoeve, 1993).

Hamka, Muhammad. Hubungan antara Persepsi Terhadap Pengawasan Kerja dengan Motivasi Berprestasi Skripsi, (Surakarta: Universitas Muhammadiyah Fakultas Psikologi, 2002).

Hasan, Muhammad Tholchah. Metodologi Peneltian Kualitatif: Tinjauan Teoritis Dan Praktis, (Surabaya: Visi Pres, 2003).

Jack C.Ricards, Longman Dictionary of anguge Teaching and Appied Linguistics, (Kuala Lumpur, Logman Group, 1999).

Jamhuri, H. Muhammad, Lc. MA. Sejarah dan Perkembangan Pendidikan Islam di Indonesia. (Tangerang: Sekolah Tinggi Agama Islam Asy-Syukriyyah,1990).

Jefkins, Frank. Public Relations Edisi kelima. (Jakarta: PT Gelora Aksara Pratama, 2003).

Kasali, Rhenald. Manajemen Public Relations: Konsep dan Aplikasinya di Indonesia. (Jakarta: PT. Pusaka Utama Grafiti. 2003).

L. Tubbs, Steward \& Sylvia Moss (editor; Deddy Mulyana). Human Communication Prinsip-prinsip Dasar. (Bandung: PT. Remaja Rosdakarya; 1996).

Lexy J. Moleong, Metode Penelitian Kualitatif, (Bandung: Remaja Rosdakarya, 2001)

Lexy J. Moleong, Metodologi Penelitian Kualitatif, (Bandung: PT Remaja Rosdakarya, 2007).

M Subana, Sudrajat, Dasara-dasar Penelitian Ilmiah, (Bandung: Pustaka Setia, 2005)

Mulyadi, Kepemimpinan Kepala Madrasah Dalam Mengembangkan BudayMutu, (Malang: Badan Litbang Dan Diklat Kementrian Agama RI, 2010).

Moh pabundu tika, Metode penelitian geografi, (Jakarta: PT Bumi Aksara, 2005). 


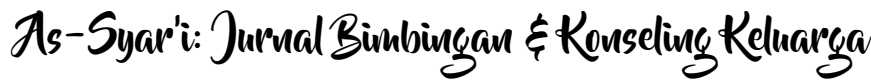

Nana Sujana dan Ibrahim, Penelitian dan Penilaian Pendidikan, (Bandung: Sinar Baru, 1989). Nasution, Metode Research, (Jakarta: Bumi Aksara, 1996).

Nana Sujana dan Ibrahim, Penelitian dan Metode, Robert K. Yin, Case Study Research: Desigs and Methods, (Beverly Hills: Sage Publication, 1987).

Newcomb, et al. Psikologi Sosial. Terjemahan. (Bandung: CV. Diponegoro. 1985).

Oliver, Sandra. Strategi Public Relations. (Penerbit Erlangga. Jakarta. 2007).

Rakhmat, Jalaluddin. Persepsi Dalam Proses Belajar Mengajar. (Jakarta: Rajawali Pers. 2007).

Robbins, P. Stephen. Perilaku Organisasi. Edisi Sembilan, Jilid 2. Edisi Bahasa Indonesia. (PT. Indeks Kelompok Gramedia, Jakarta. 2003).

Ruslan, Rosady. Manajemen Public Relations dan Media Komunikasi,80. (Jakarta: Rajawali Pers, 2010).

Sarwono, Sarlito Wirawan. Pengantar Umum Psikologi. (Jakarta: Bulan Bintang. 1983).

Sarwono, Sarlito W. dan Eko A. Meinarno. Psikologi Sosial. (Jakarta: Penerbit Salemba Humanika, 2009).

Sears, David 0. dkk, Social Psychology Fifth Edition (Alih Bahasa: Andryanto). (Jakarta: Erlangga, 1985).

Shirley Harrison. Media Relations: Konsep, Pendekatan dan Praktik. (Bandung: PT. Rosdakarya. 2005).

Slameto. Belajar dan faktor-faktor yang mempengaruhinya. (Jakarta: Rineka Cipta. 2010).

Soemirat, Soleh \& Ardianto, Elvinaro. Dasar-dasar Public Relations. (Bandung: Rosdakarya. 2007).

Sugiyono. Metode Penelitian Kuantitatif Kualitatif dan R\&D. (Bandung: Alfabeta, 2006).

Sugihartono, dkk. Psikologi Pendidikan. (Yogyakarta: UNY Press. 2007).

Sugiono, Metode Penelitian Pendidikan Pendekatan Kuantitatif, Kualitatif, R\&D, (Bandung: Alfabeta cv, 2010).

Sukardi, Dewa Ketut. Bimbingan Karir Sekolah Menengah. (Jakarta: Asdi Mahastya. 1994).

Sukardi, Metodologi penelitian kualitatif Kompetensi dan prakteknya, (Jakarta: Bumi aksara, 2004).

Suryobroto. Beberapa Aspek Dasar-dasar Kependidikan. (Yogyakarta: Bina Aksara, 1983).

Sutojo, Siswanto. Membangun Citra Perusahaan: Building the Corporate Image. (Jakarta: PT. Damar Mulia Pustaka. 2004).

Suyanto, Agus. Psikologi Umum. (Jakarta: Aksara Baru, 1992).

Tjiptono, Fandi, Strategi Pemasaran, (Yogyakarta, ANDI Yogyakarta, 1997).

Toha, Miftah. Perilaku Organisasi, Konsep dan Aplikasinya. (Jakarta: PT. Raja Grafindo Persada. 2005).

Walgito, Bimo. Psikologi Sosial (Suatu Pengantar). Edisi Revisi. (Yogyakarta: Andy Offset. . 1991). Walgito, Bimo. Psikologi Umum. (Andi, Jakarta. 2004).

Walgito, Bimo. Pengantar Psikologi Umum. (Yogyakarta: C.V. Andi Offset. 2010). 